\title{
The prevalence and intensity of external and internal parasites in working donkeys (Equus asinus) in Egypt
}

\author{
Marwa M. Attia ${ }^{1}$, Marwa M. Khalifa ${ }^{1}$ and Marwa Th. Atwa \\ 1. Department of Parasitology, Faculty of Veterinary Medicine, Cairo University, Giza, Egypt; 2. Department of Zoology, \\ Faculty of Science, Al-Fayoum University, Egypt. \\ Corresponding author: Marwa M. Attia, e-mail: marwaattia.vetpara@yahoo.com \\ Co-authors: MMK: marwaehab40@yahoo.com, MTA: mta00@fayoum.edu.eg \\ Received: 14-05-2018, Accepted: 26-07-2018, Published online: 19-09-2018
}

doi: 10.14202/vetworld.2018.1298-1306 How to cite this article: Attia MM, Khalifa MM, Atwa MT (2018) The prevalence and intensity of external and internal parasites in working donkeys (Equus asinus) in Egypt, Veterinary World, 11(9):1298-1306.

\begin{abstract}
Aim: This study aims to record and update the prevalence and intensity of external and internal parasites in working donkeys (Equus asinus) in Egypt during the period from January to December 2017.

Materials and Methods: A total of 120 donkeys (10 donkeys each month) were examined at Giza zoo abattoir through bimonthly visits. The examined donkeys were obtained from five governorates (Giza [20], Fayoum [40], Beni Suef [30], Monofia [20], and Assiut [10]). The animals were grouped according to age and sex.

Results: All examined donkeys were positive with at least one internal or even external parasitic species. The overall prevalence rate was $100 \%$. A total of 11 helminths species (10 nematodes and 1 metacestode); 7 protozoal and 7 arthropod species were collected. The number of each parasite and intensity of infection with regard to age and sex was recorded.
\end{abstract}

Conclusion: All examined donkeys were infected with parasites with an overall prevalence of 100\%. So, we recommended following up and continuous treatment of such diseased animal.

Keywords: arthropods, donkeys, Egypt, external parasites, helminths, internal parasites, protozoa.

\section{Introduction}

More than 40 million donkeys are distributed throughout the world [1]. The donkey population in Africa is estimated to be 13 million [2]. According to the latest Food and Agriculture Organization statistics, there are approximately 3 million working donkeys in Egypt. The working donkeys, horses, and mules carry out a wide range of work types. These animals are used for transportation of passengers and goods by carts in urban areas in the busy cities and towns.

The most important problems for equines and donkeys in developing countries are gastrointestinal parasitism [3]. Donkeys harbor a large number of parasites including roundworms (families: Stronglidae, Oxyuridae, Trichostronglidae, and Ascaridae), flatworms (Fasciolidae), and tapeworm (family: Anoplocephalidae) which damage the intestine depending on the species and number of parasites [3]. Infections with endoparasites cause loss of condition, poor reproduction of animals, colic, and diarrhea [4].

Furthermore, blood protozoal diseases are one of the important parasitic infections which affect family Equidae in Egypt. Equine piroplasmosis is the tickborne disease caused by Theileria equi (Babesia equi)

Copyright: Attia, et al. Open Access. This article is distributed under the terms of the Creative Commons Attribution 4.0 International License (http://creativecommons.org/licenses/by/4.0/), which permits unrestricted use, distribution, and reproduction in any medium, provided you give appropriate credit to the original author(s) and the source, provide a link to the Creative Commons license, and indicate if changes were made. The Creative Commons Public Domain Dedication waiver (http://creativecommons.org/ publicdomain/zero/1.0/) applies to the data made available in this article, unless otherwise stated. which causes abortions, loss of performance, and death [5]. Trypanosomes are blood parasites found in mammals including donkeys; Trypanosoma evansi which is one of the trypanosomes infecting donkeys [6].

This study aims to record and update the prevalence and intensity of external and internal parasites in working donkeys (Equus asinus) in Egypt during the period from January to December 2017.

\section{Materials and Methods}

\section{Ethical approval}

This study was approved by the Ethical Committee, Faculty of Veterinary Medicine, Cairo University with number CU/II/F/18/103.

\section{Animals}

During the period from January to December 2017, 120 donkeys (10 donkeys each month) were examined at postmortem in Giza Zoo abattoir (Giza, Egypt) through bimonthly visits, for the detection of internal and external parasitic infection. The donkeys were obtained from five governorates (Giza [20], Fayoum [40], Beni Suef [30], Monofia [20], and Assiut [10]). The animals were grouped according to age as from 1 to 2 years (25), 3-5 years (35), and 6-8 years (60), of which 90 donkeys were male and 30 were female. The animals were field working donkeys, fed on green ration, and never received any antiparasitic medications. These animals send for slaughtering in this abattoir are usually emaciated and unsuitable for working. Each donkey was physically examined before slaughtering, for determination of the age and sex as well as examination of external parasites on skin. 


\section{Fecal sample collection and examination}

Fecal samples were collected directly from the rectum of donkeys before slaughtering. The feces were collected in separate polyethylene bags and labeled for identification. Microscopic examination of the samples was performed in the Laboratory of the Parasitology Department in the Faculty of Veterinary Medicine, Cairo University, Giza, Egypt. The gross fecal examination was done for the collection of adult nematodes and/or the gravid segment of cestodes.

\section{Microscopic fecal examination}

\section{Direct smear method}

A small amount of feces was placed on the clean glass slide and mixed with a drop of water; a coverslip was applied on the fecal smear and examined under the microscope to detect and identify the parasitic ova [7].

\section{Floatation and sedimentation technique}

\section{Floatation technique}

One $\mathrm{g}$ of feces was diluted with $10 \mathrm{ml}$ of saturated salt solution in the test tube which was filled to the top with the salt. A clean cover glass slip was sideways over the top of the tube. After $10 \mathrm{~min}$, the cover was taken onto the slide and examined under the light microscope using the magnification power 40 and $100 \times$.

\section{Sedimentation method}

Two $g$ of feces was dissolved in tap water in a beaker and allowed the mixture to sediment without disturbing for 20-30 min. The supernatant was poured off to collect the sediment for examination [7]. A small amount of the sediment was transferred to a small Petri dish and examined under the light microscope using the magnification power 40 and $100 \times$.

\section{Examination of gastrointestinal samples}

The samples were collected from stomach and small and large intestine after slaughtering the donkeys for detection of parasites as following:

Stomach and intestinal contents from every donkey were examined separately by naked eyes, the larvae and adult worms were collected. The collected samples were placed in a separate vial containing a saline solution $(0.9 \% \mathrm{NaCl})$. The wall of the stomach and intestine were washed separately, and these washings were collected for subsequent examination. All of the collected helminths were preserved in $70 \%$ glycerol alcohol for subsequent identification. The stomach larvae (Gasterophilus spp.) were collected in 70\% ethanol until identification study.

Smears were made from each intestinal sample of different parts of the intestine for examination of Cryptosporidium species. Each sample was mixed thoroughly with the drop of saline and spread on glass slides which left to air dry at the room temperature, fixed by absolute methanol for $10 \mathrm{~min}$ and stained with modified Ziehl-Neelsen stain technique [8]. Other smears were made and also fixed in absolute methanol which stained with Giemsa stain for examination of other enteric protozoa.

\section{Examination of tissue for detection of Sarcocystis spp.}

Samples from esophagus, heart, tongue, and diaphragm were fixed in 10\% formalin and processed as recorded by Bancroft and Stevens [9]. Sections were deparaffinized and stained with hematoxylin and eosin stain for histological examination by light microscopy.

\section{Blood samples}

Blood samples were collected directly from the jugular vein into heparinized test tubes at the time of slaughtering. Thin blood smears were made and left to air dry. The smears were fixed with absolute methanol and stained with Giemsa stain. Slides were examined under a microscope using the oil immersion lens for the identification of blood parasites [7].

\section{External parasites}

The skin was carefully examined for the presence of any external parasites such as ticks and any insect's flies which were identified using a stereoscopic microscope. Skin scraping was done if keratinization was present in the skin according to Soulsby [7].

\section{Cellophane tape technique}

To detect the eggs of pinworms (Oxyuris equi), female nematodes were protruded from the anus and deposited their eggs on the skin around the anus. The cellophane tape was used around the anus and then placed it on the slide with the small drop of water and examined under a light microscope with magnification X40, X100, and X400.

\section{Identification of the parasites}

The nematodes were washed several times with phosphate buffer saline ( $\mathrm{pH} 7.2)$, then preserved in $70 \%$ glycerin alcohol. The nematodes were cleared using lactophenol, then mounting by gelatin. All identifications of the helminths and their eggs were carried out following the morphological description [7,10-12]. All arthropod larvae, fleas, ticks, and mites, as well as all protozoan parasites, were identified according to Soulsby [7].

\section{Statistical analysis}

The prevalence of infection and intensity was calculated using Chi-square test, with determination of mean intensity related to governorates [13]. Significance was analyzed using the SPSS v.11.0. In all cases, $\mathrm{p}<0.05$ were considered for the statistically significant difference.

\section{Results}

All the donkeys examined were positive with at least with one internal or external parasitic species. The overall prevalence rate was 100\%. A total of 11 helminths species (10 nematodes and 1 metacestode) were recorded. Higher prevalence was 
estimated in Cylicocyclus asini (91.66\%) followed by Cyathostomum spp. (83.33\%) while lower prevalence recorded in Draschia megastoma and hydatid cyst $(8.33 \%)$. The helminths species and their prevalence are given in Table-1 and Figures-1, 2, 3b-d, and 4.

A total of seven protozoal species were recorded with the most prevalent one being Balantidium coli with $91.6 \%$ and the lowest prevalent one being Cryptosporidium spp. $6.66 \%$ which was present mainly in young donkeys aged between 1 and 2 years and become lower at the older age. The rates of Sarcocystis infection in the esophagus, tongue, diaphragm, and heart were $80 \%, 97 \%, 40.0 \%$, and $14 \%$, respectively. The rates of detection by age were as follows: 1-2 years old $17 \%, 3-5$ years old $45 \%$, and 6-8 years old 50\% (Table-2 and Figures- 5 and 6).

The findings on the arthropods in this study include 7 species were recorded with highest infestation rate in Gasterophilus intestinalis (97.5\%) and

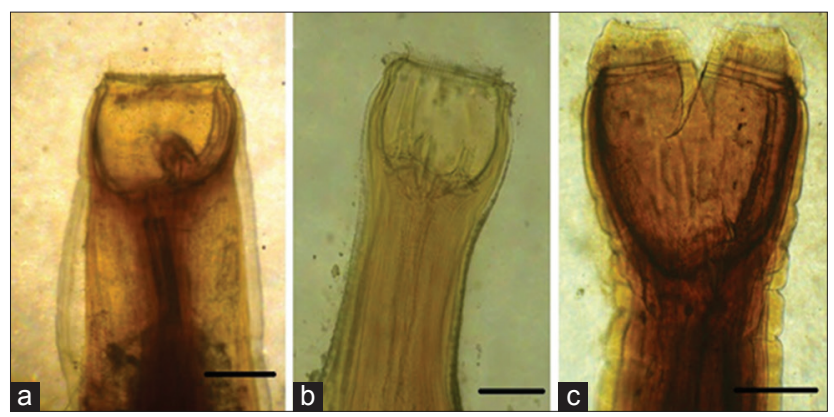

Figure-1: Strongylus spp. infecting large intestine of donkeys (notes its buccal capsules). (a) Strongylus vulgaris (two ear-shaped subdorsal teeth), (b) Strongylus equinus (three teeth; one large bifid teeth and two smaller one), (c) Strongylus edentatus (buccal capsules with no teeth), Scale bar $100 \mu \mathrm{m}$.
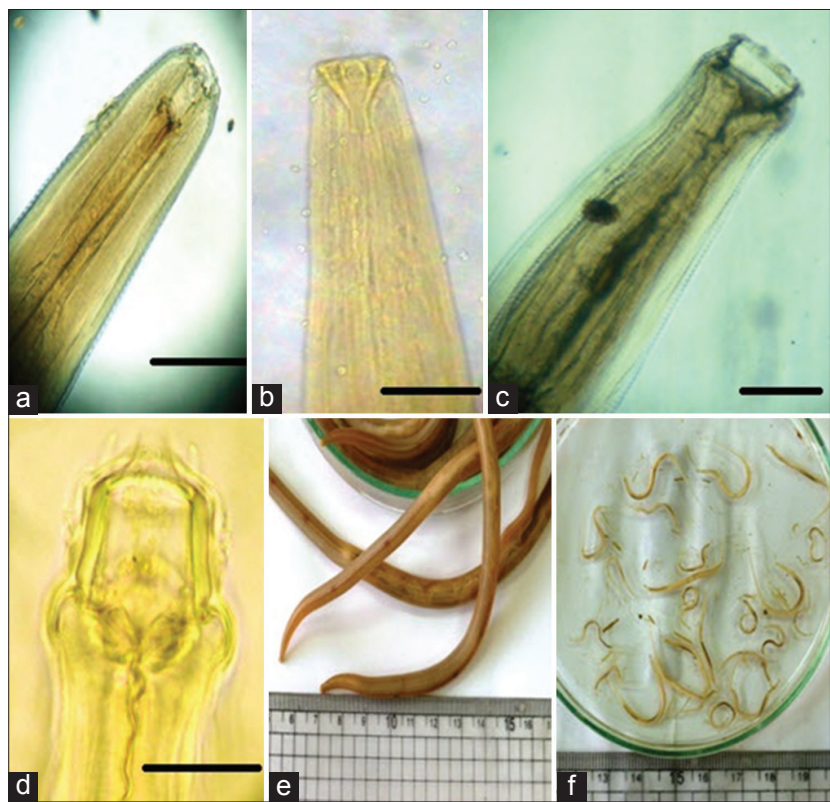

Figure-2: (a) Habronema muscae (cylindrical pharynx), (b) Habronema megastoma (funnel-shaped pharynx), (c) Cylicocyclus asini, (d) Cyathostomum spp., (e) Parascaris equorum (large lips), (f) Oxyuris equi (pinworm). lower infestation rate recorded in Haematopinus asini and P. equi (8.33\%) (Table-3 and Figures-3a and 7).

As for the sex in our study, males were high in B. coli $(100 \%)$ followed by G. intestinalis $(96.66 \%)$ and $C$. asini $(88.88 \%)$. The prevalence in males was lower in Cryptosporidium spp. (6.66\%), H. asini (4.44\%), and hydatid cyst (4.44\%).

The prevalence in females was higher in G. intestinalis, C. asini (100\%), Sarcocystis spp., and B. coli (66.66\%), while lower in Rhipicephalus spp., Eimeria leuckarti, Cryptosporidium spp. (6.66\%), and D. megastoma $(10 \%)$.

With regard to age in this study, the age from 1 to 2 years was higher in Parascaris equorum (100\%), G. intestinalis $(88 \%)$, and B. coli $(80 \%)$ and lower in Entamoeba coli, Habronema muscae (12\%), and $H$. asini (4\%). In age ranged from 3 to 5 years, $G$. intestinalis (100\%), H. muscae (90\%), Sarcocystis spp., B. coli, and C. asini $(85.71 \%)$ and lower in Cryptosporidium spp., Boophilus spp. (5.71\%), and hydatid cyst $(8.57 \%)$. In age ranged from 6 to 8 years, G. intestinalis, Gasterophilus nasalis, B. coli, Cyathostomum spp., and C. asini were $100 \%$, while in E. leuckarti (6.66\%), H. asini (8.33\%), and D. megastoma $(10 \%)$.

Regarding geographical distribution of parasitic infection in Egyptian donkeys, the four governorates were positive for single or mixed infection. The Giza governorate was higher in C. asini (75\%),

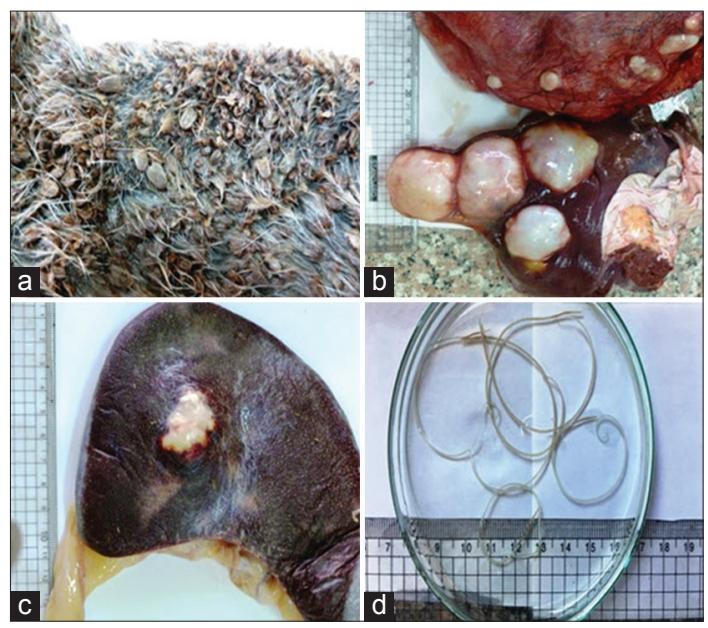

Figure-3: (a) Skin heavily infested with ticks, (b and c) hydatid cyst in liver, lung, and spleen, (d) Setaria equina (filarial nematodes of equines from the peritoneal cavity).

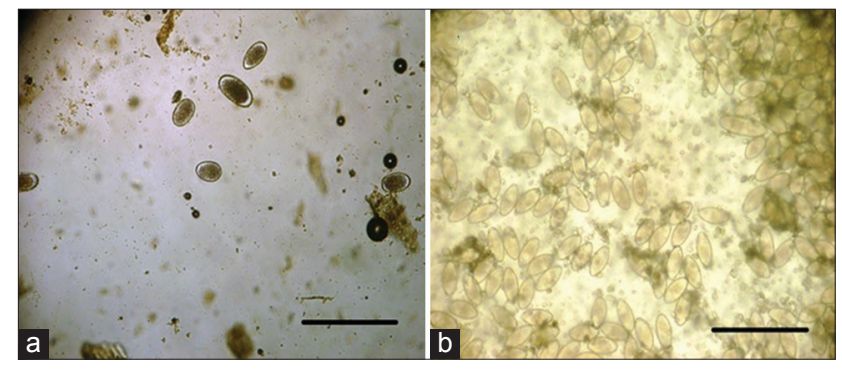

Figure-4: (a) Strongylus eggs, (b) Oxyuris equi eggs with cellophane tape techniques, Scale bar $100 \mu \mathrm{m}$. 
Table-1: Prevalence and mean intensity of helminth parasites infecting donkeys.

\begin{tabular}{|c|c|c|c|c|c|c|c|}
\hline \multirow[t]{2}{*}{ Parasites } & \multirow{2}{*}{$\begin{array}{c}\text { No. } \\
\text { infected (\%) }\end{array}$} & \multirow{2}{*}{$\begin{array}{c}\text { Range } \\
\text { (intensity) }\end{array}$} & \multicolumn{2}{|c|}{ Sex } & \multicolumn{3}{|c|}{ Age } \\
\hline & & & M (\%) & F (\%) & $1-2$ & 3-5 & $6-8$ \\
\hline Habronema muscae & $90(75)$ & $50-300(80)$ & $65(72.22)$ & $25 *(83.33)$ & $3(12)$ & $32 * *(91.42)$ & $55(91.66)$ \\
\hline Draschia megastoma & $10(8.33)$ & $2-10(7)$ & $7(7.77)$ & $3(10)$ & - & $4(11.42)$ & $6 *(10)$ \\
\hline Parascaris equorum & $30(25)$ & $15-40(25)$ & $24(26.66)$ & $6 * *(20)$ & $25(100)$ & $5 * *(14.28)$ & - \\
\hline Strongylus vulgaris & $20(16.66)$ & $1-110(30)$ & $9(10)$ & $11(36.66)$ & - & $8(22.85)$ & $12(20)$ \\
\hline Strongylus equinus & $30(25)$ & $2-45(15)$ & $13(14.44)$ & $17(56.66)$ & - & $12(34.28)$ & $18(30)$ \\
\hline Strongylus edentatus & $30(25)$ & $2-55(20)$ & $12(13.33)$ & $18(60)$ & - & $10(28.57)$ & $20 *(33.33)$ \\
\hline Cyathostomum spp. & $100(83.33)$ & $20-100(50)$ & $85(94.44)$ & $15 * *(50)$ & $12(48)$ & $28 *(80)$ & $60(100)$ \\
\hline Cylicocyclus asini & $110(91.66)$ & $5-26(15)$ & $80(88.88)$ & $30 *(100)$ & $20(80)$ & $30(85.71)$ & $60(100)$ \\
\hline Oxyuris equi & $60(50)$ & $7-30(10)$ & $34(37.77)$ & $26(86.66)$ & $18(72)$ & $30 *(85.71)$ & $12(20)$ \\
\hline Setaria equina & $30(25)$ & $1-15(5)$ & $12(13.33)$ & $18(60)$ & - & $12(34.28)$ & $18(30)$ \\
\hline Hydatid cyst & $10(8.33)$ & $1-3(1)$ & $4(4.44)$ & $6(20)$ & - & $3(8.57)$ & $7(11.66)$ \\
\hline
\end{tabular}

${ }^{*} \mathrm{p} \leq 0.05 ; * * \mathrm{p} \leq 0.01, \mathrm{M}$ : Male, F: Female

Table-2: Prevalence of protozoal infection in donkeys $(n=120)$ with reference to sex and age.

\begin{tabular}{|c|c|c|c|c|c|c|}
\hline \multirow[t]{2}{*}{ Protozoa } & \multirow[t]{2}{*}{ No. infected } & \multicolumn{2}{|c|}{ Sex } & \multicolumn{3}{|c|}{ Age } \\
\hline & & M (\%) & F (\%) & $1-2(\%)$ & $3-5(\%)$ & $6-8(\%)$ \\
\hline Eimeria leuckarti & $10(8.33)$ & $8(8.88)$ & $2(6.66)$ & - & 6* (17.14) & $4(6.66)$ \\
\hline Cryptosporidium spp. & $8(6.66)$ & $6(6.66)$ & $2(6.66)$ & $6(24)$ & $2 *(5.71)$ & - \\
\hline Sarcocystis spp. & $80(66.66)$ & $60(66.66)$ & $20 * *(66.66)$ & - & $30(85.71)$ & $50(83.33)$ \\
\hline Balantidium coli & $110(91.66)$ & $90(100)$ & $20 * *(66.66)$ & $20(80)$ & $30(85.71)$ & $60 *(100)$ \\
\hline Entamoeba coli & $30(25)$ & $26(28.88)$ & 4* (13.33) & $3(12)$ & $20(57.14)$ & $7 * *(11.66)$ \\
\hline Theileria equi & $20(16.66)$ & $16(17.77)$ & $4(13.33)$ & - & $8(22.85)$ & $12(20)$ \\
\hline Trypanosoma evansi & $16(13.33)$ & $12(13.33)$ & $4(13.33)$ & - & $6(17.14)$ & $10(16.66)$ \\
\hline
\end{tabular}

$*_{\mathrm{p}} \leq 0.05 ; * * \mathrm{p} \leq 0.01, \mathrm{M}$ : Male, F: Female

Table-3: Prevalence and mean intensity of arthropod parasites infected donkeys.

\begin{tabular}{|c|c|c|c|c|c|c|}
\hline \multirow[t]{2}{*}{ Arthropods } & \multirow[t]{2}{*}{ No. infected $(\%)$} & \multicolumn{2}{|c|}{ Sex } & \multicolumn{3}{|c|}{ Age } \\
\hline & & M (\%) & F (\%) & $1-2$ & 3-5 & $6-8$ \\
\hline Gasterophilus intestinalis & $117(97.5)$ & $87(96.66)$ & $30 * *(100)$ & $22(88)$ & $35(100)$ & $60 *(100)$ \\
\hline Gasterophilus nasalis & $80(66.66)$ & $68(75.55)$ & $12 * *(40)$ & - & $20(57.14)$ & $608(100)$ \\
\hline Boophilus spp. & $12(10)$ & $10(11.11)$ & $2 *(6.66)$ & - & $2(5.7)$ & $10(16.66)$ \\
\hline Hippobosca equina & $15(12.5)$ & $7(7.77)$ & $8(26.66)$ & - & $6(17.14)$ & $9(15)$ \\
\hline Haematopinus asini & $10(8.33)$ & $4(4.44)$ & $6(20)$ & $1(4)$ & $4(11.42)$ & $5(8.33)$ \\
\hline Ctenocephalides felis & $70(58.33)$ & $47(52.22)$ & $23 *(76.66)$ & $15(60)$ & $25(71.42)$ & $30(50)$ \\
\hline Psoroptes equi & $10(8.33)$ & $7(7.77)$ & $3(10)$ & - & $4(11.42)$ & $6(10)$ \\
\hline
\end{tabular}

$* \mathrm{p} \leq 0.05 ; * * \mathrm{p} \leq 0.01, \mathrm{M}$ : male, F: female

B. coli $(80 \%)$, and G. intestinalis $(90 \%)$ and lower in S. equina, T. equi, and P. equi (5\%).

The prevalence rate in Fayoum governorate was higher in H. muscae, Cyathostomum spp., C. asini, and G. intestinalis (100\%) and lower in Cryptosporidium spp. and P. equi $(12.5 \%)$.

The prevalence rate in Beni Suef governorate was higher in $G$. intestinalis $(100 \%)$ and lower in hydatid cyst and Cryptosporidium spp. (3.33\%). While in Monofia the highest prevalence rate of infestation was recorded in G. intestinalis $(95 \%)$ and $C$. asini (90\%) and lower in D. megastoma, $S$. equina, and $P$. equi (5\%). The prevalence studies in Assiut governorate were higher in Cyathostomum spp., B. coli, T. evansi, and G. intestinalis (100\%), and lower prevalence was recorded in D. megastoma $(10 \%)$. The geographical distribution of each parasite in examined governorates is recorded in Table-4.

\section{Discussion}

Dealing with helminths, in our study $H$. muscae was recorded in $75 \%$ of infected donkeys while in [14-16] recorded $55-90 \%$ of donkeys. This indicates that the distribution of this parasite among equines all over the world is quite serious, also indicates the wide distribution of the intermediate host (Musca domestica) in Egypt.

In the present study, D. megastoma was reported $8.33 \%$ while in the other studies performed in different areas of the world, D. megastoma was reported in 0.69$47 \%$ of donkeys $[14,15]$, other studies did not record D. megastoma in any groups of family Equidae [17].

The prevalence of $P$. equorum was $25 \%$, which is less than the results recorded by Shrikhanda et al. [17] $29.26 \%$ and $43 \%$ recorded by Ayele et al. [18]. This may be due to different grazing areas around family Equidae and the lack of awareness about the health of 


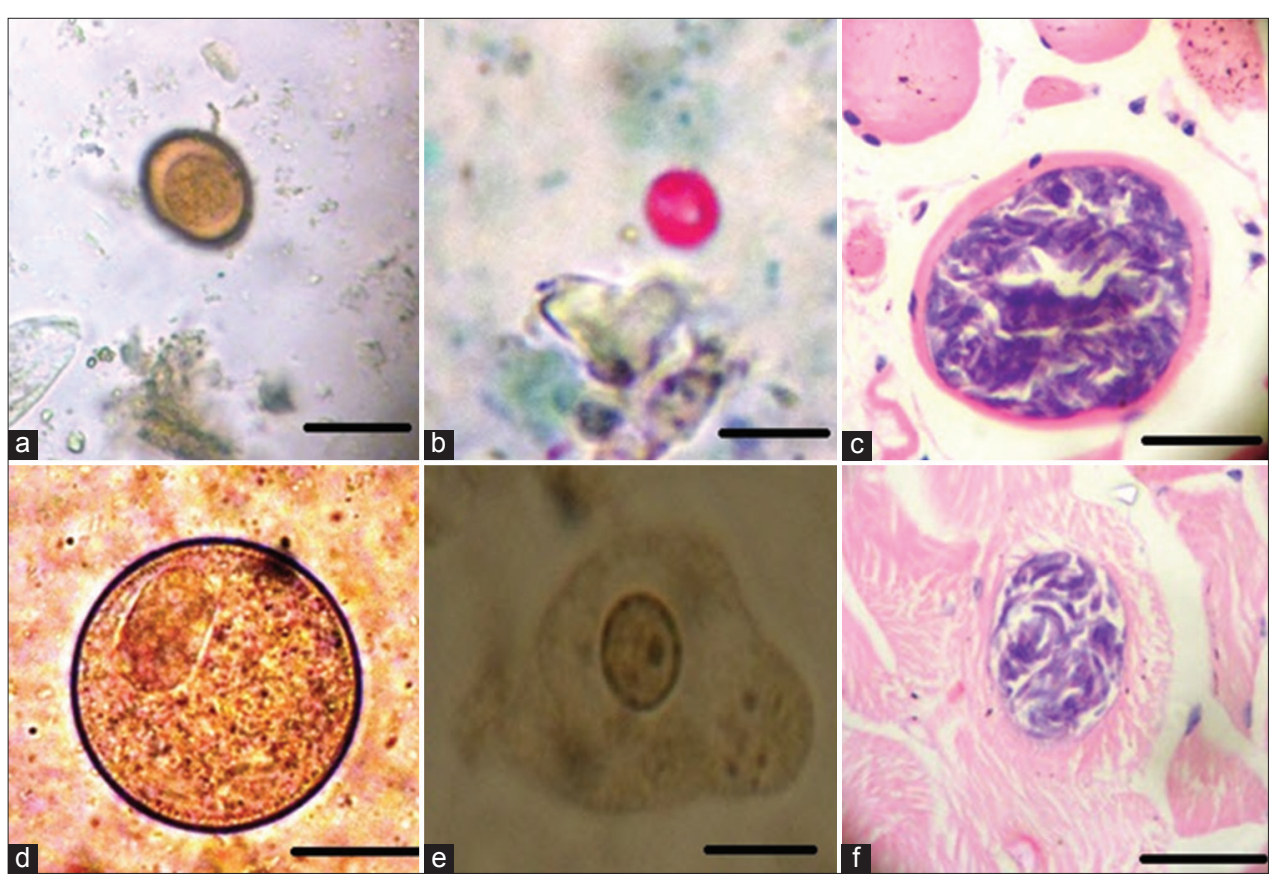

Figure-5: Protozoan parasites infection donkeys. (a) Eimeria leuckarti, (b) Cryptosporidium spp., (c and f) Sarcocystis spp. in muscles and heart, (d) Balantidium coli, (e) Entamoeba coli vegetative form. Scale bar $50 \mu \mathrm{m}$.

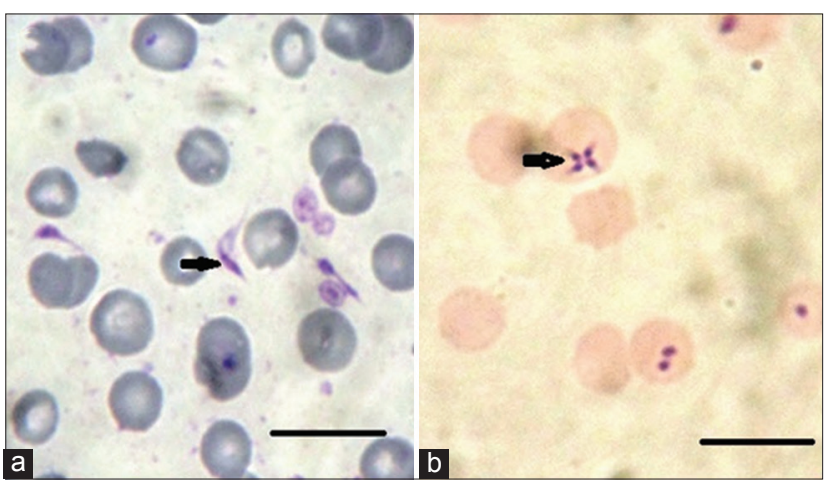

Figure-6: (a) Trypanosoma evansi, (b) Theileria equi; blood smears stained with Giemsa stain. Scale bar $10 \mu \mathrm{m}$.

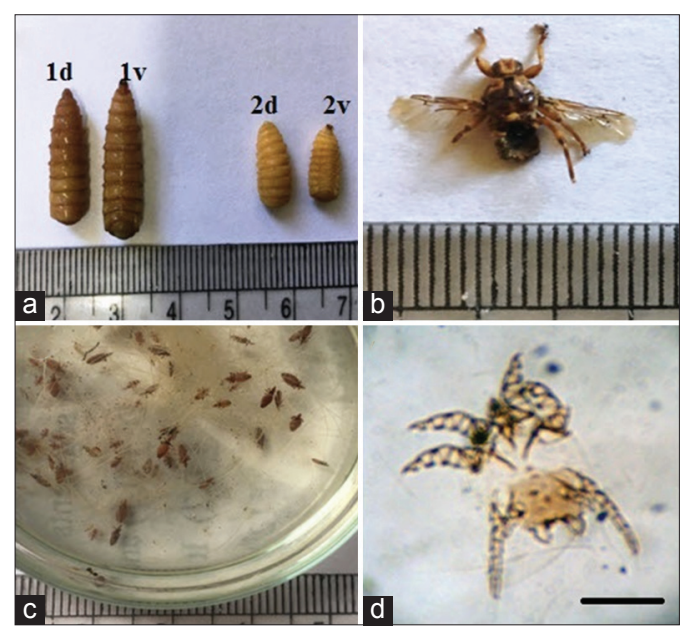

Figure-7: Ectoparasites infesting donkeys. (a) Gasterophilus intestinalis (1) $1 \mathrm{~d}$ on dorsal view, $1 \mathrm{v}$ on ventral view, 2: Gasterophilus nasalis, $2 \mathrm{~d}$ on dorsal surface; $2 \mathrm{v}$ on ventral surface. (b) Hippobosca equina, (c) Haematopinus asini, (d) Psoroptes equi, scale bar100 $\mu \mathrm{m}$. animals in these areas, while the current prevalence of P. equorum (25\%) was higher than the previous record of $17.3 \%$ by Fikru et al. [19].

The prevalence of Strongylus spp. disagreed with the result of $99.5 \%$ [17], $100 \%$ by Alemayehu [20], $96.77 \%$ by Sinasi [21], and $92 \%$ by Ayele and Dinka [22]. The different findings might be due to the differences in the climate, agro-ecological conditions, variation in sample size, and sampling method differences [23]. In addition, this might be associated with donkeys which could be neglected in these areas, kept under poor management conditions, and receiving less attention from owners [24].

Due to the difficulty in the identification and complex taxonomy of cyathostomins, few workers have identified these parasites to the species level in donkeys [25-28]. In the present study, Cyathostomum spp. was recorded with the prevalence rate of $91.66 \%$, this is very high and agreed with the work of Getachew et al. [29], who found 17 species of cyathostomins in Ethiopian donkeys. This similarity could be regarded to near similarity of agro-ecological conditions in both countries.

The prevalence of $O$. equi was $50 \%$, and this is higher than $8.53 \%$ recorded by Shrikhanda et al. [17] and $6.4 \%$ recorded by Sinasi [21]. This may be due to the differences between the management systems and climatic conditions between the study areas [23].

The low prevalence of hydatid cyst $(8.33 \%)$ found in this study is agreed with the findings in donkeys at Donkey Sanctuary, UK [30]. This result might be attributed to the sporadic discharge of gravid segments of E. granulosus adult in the feces 
Table-4: Prevalence of infection by different parasites in examined governorates.

\begin{tabular}{|c|c|c|c|c|c|c|}
\hline \multirow[t]{2}{*}{ Parasites } & \multicolumn{6}{|c|}{ Number of positive donkeys (\%) } \\
\hline & Governorates & $\begin{array}{c}\text { Giza } \\
n=20\end{array}$ & $\begin{array}{c}\text { Fayoum } \\
n=40\end{array}$ & $\begin{array}{c}\text { Beni Suef } \\
\mathbf{n}=\mathbf{3 0}\end{array}$ & $\begin{array}{c}\text { Monofia } \\
n=20\end{array}$ & $\begin{array}{c}\text { Assiut } \\
n=10\end{array}$ \\
\hline \multirow[t]{11}{*}{ Helminths } & Habronema muscae & $10(50)$ & $40(100)$ & $23(76.66)$ & $9(45)$ & $8(80)$ \\
\hline & Draschia megastoma & - & $6(15)$ & $2(6.66)$ & $1(5)$ & $1(10)$ \\
\hline & Parascaris equorum & - & $20(50)$ & $2(6.66)$ & $3(15)$ & $5(50)$ \\
\hline & Strongylus vulgaris & - & $15(37.5)$ & $2(6.66)$ & - & $3(30)$ \\
\hline & Strongylus equinus & - & $20(50)$ & $4(13.33)$ & $1(5)$ & $5(50)$ \\
\hline & Strongylus edentatus & - & $21(52.5)$ & $5(16.66)$ & $2(10)$ & $2(20)$ \\
\hline & Cyathostomum spp. & $10(50)$ & $40(100)$ & $27(90)$ & $13(65)$ & $10(100)$ \\
\hline & Cylicocyclus asini & $15(75)$ & $40(100)$ & $28(93.33)$ & $18(90)$ & $9(90)$ \\
\hline & Oxyuris equi & $2(10)$ & $25(62.5)$ & $20(66.66)$ & $8(40)$ & $5(50)$ \\
\hline & Setaria equina & $1(5)$ & $20(50)$ & $2(6.66)$ & - & $7(70)$ \\
\hline & Hydatid cyst & - & $7(17.5)$ & $1(3.33)$ & - & $2(20)$ \\
\hline \multirow[t]{7}{*}{ Protozoa } & Eimeria leuckarti & - & $7(17.5)$ & $3(10)$ & - & - \\
\hline & Cryptosporidium spp. & - & $5(12.5)$ & $1(3.33)$ & - & $2(20)$ \\
\hline & Sarcocystis spp. & $3(15)$ & $37(92.5)$ & $26(86.66)$ & $5(25)$ & $9(90)$ \\
\hline & Balantidium coli & $16(80)$ & $39(97.5)$ & $28(93.33)$ & $17(85)$ & $10(100)$ \\
\hline & Entamoeba coli & - & $23(57.5)$ & $5(16.66)$ & - & $2(20)$ \\
\hline & Theileria equi & $1(5)$ & $25(62.5)$ & - & - & $4(40)$ \\
\hline & Trypanosoma evansi & - & $6(15)$ & - & - & $10(100)$ \\
\hline \multirow[t]{7}{*}{ Arthropoda } & $\begin{array}{l}\text { Gasterophilus } \\
\text { intestinalis }\end{array}$ & $18(90)$ & $40(100)$ & $30(100)$ & $19(95)$ & $10(100)$ \\
\hline & Gasterophilus nasalis & - & $35(87.5)$ & $28(93.33)$ & $10(50)$ & $7(70)$ \\
\hline & Boophilus spp. & - & $6(15)$ & - & - & $6(60)$ \\
\hline & Hippobosca equina & - & $9(22.5)$ & - & - & $6(60)$ \\
\hline & Haematopinus asini & - & $6(15)$ & $1(3.33)$ & - & $3(30)$ \\
\hline & Ctenocephalides felis & $2(10)$ & $36(90)$ & $15(50)$ & $8(40)$ & $9(90)$ \\
\hline & Psoroptes equi & $1(5)$ & $5(12.5)$ & - & $1(5)$ & $3(30)$ \\
\hline
\end{tabular}

$\mathrm{n}=$ Number of examined donkeys in each governorate

of dogs and donkeys acts as intermediate host of this helminth [29].

The present study indicated that among different types of helminth parasites, H. muscae, Cyathostomum spp., and Strongylus spp. were found to be dominant in the study. With regard to sex, generally, the helminths parasites were found in females more than males. This might be due to the fact that males are less exposed to infection because they tend to be more solitary [31]. In addition, the female donkeys have a higher infestation because they have lower immunity due to gestation, lactation, and stress occurring during this period [32].

It is assumed that sex is a determinant factor influencing the prevalence of parasitism [33]. With regard to age, the highest prevalence of helminths were seen in old age, and this may be due to loss of body conditions and decrease of immunity,whereas the age of the animal increases, the immunity decreases [32], except in harboring by $P$. equorum where this parasite was found in young equines more than older ones. This might have been because the donkeys were too old to harbor this parasite [25]. In addition, P. equorum is a problem of young equines as the animals have not yet developed immunity [32].

The prevalence of Cryptosporidium spp. in donkeys was $6.6 \%$ ( 8 out of 90 ). The low prevalence of Cryptosporidium spp. agrees with Souza et al. [34], Laatamna et al. [35], Majewska et al. [36], and Sturdee et al. [37]. In contrast, high prevalence rate reported between 10 and $31 \%$ by Caffara et al. [38], Grinberg et al. [39], and Wannas et al. [40]. In the present study, Cryptosporidium spp. was found mainly in young age between 1 and 2 years and became lower at the older age (3-5 years). This finding disagrees with Laatamna et al. [35] who found it in age $>3$ years, and not in young one. The Cryptosporidium spp. was found in males and females, but Laatamna et al. [35] found only in males.

Our results indicated that the prevalence of E. leuckarti in donkeys was $8.33 \%$, which is nearly similar to Studzinska et al. [41] (7\%) and Ghahfarrokhi et al. [42] (7.68\%). In our investigated data that disagreed with Wannas et al. [40] and Atawalna et al. [43] recorded high prevalence of $10.71 \%$ and $10.3 \%$, respectively, but Nakayima et al. [44] found that infection rate was 3.58\% and Souza et al. [34] found the prevalence of $E$. leuckarti lower than $1 \%$. In our investigations, six donkeys, from 3 to 5 years old, were infected, and four animals were 6-8 years old. This result disagreed with the presence of E. leuckarti more in young one as Souza et al. [34], but Ghahfarrokhi et al. [42] found $2(7.6 \%)$, one 2 years old and another 10 years old. Moreover, in our study, infection by E. leuckarti was found in 8 males and 2 females. This agreed with Ghahfarrokhi et al. [42] who found in male and female, but Souza et al. [34] found it in females only. These differences may be due to geographical variations and various ages and coproscopy methods used [41]. 
Sarcocystis spp. was isolated from $66.66 \%$ $(80 / 120)$ of the donkeys. This result disagreed with Fukuyo et al. [45] (93.0\% in horses). The rates of detection in the esophagus, tongue, diaphragm, and heart were $80 \%, 97 \%, 40.0 \%$, and $14 \%$, respectively. The rates of detection of infection in relation to age are as follows: $1-2$ years old $17 \%, 3$-5years old $45 \%$, and $6-8$ years old $50 \%$. The distribution of the Sarcocystis spp. in esophagus, tongue, diaphragm, and heart muscle was positively correlated with horse age. The infection with Sarcocystis spp. was increased with increasing of age [45].

In our results, $B$. coli infection in donkeys was 91.66\%. These results disagree with Wannas et al. [40] and Khan et al. [46] who found infection $17.85 \%$ and $18.3 \%$ in donkeys, respectively. While E. coli infection in our results was $25 \%$, which is nearly similar to Dissanayake et al. [47] in horses (28.8\%). This result disagreed with Wannas et al. [40], who recorded $3.57 \%$ in donkeys.

The hemoparasites seen on microscopy were T. equi and T. evansi at low parasitemia in $16.66 \%$ and $13.33 \%$, respectively. These findings disagreed with Mushi et al. [48], who had seen the only hemoparasite to be T. equi in $26.8 \%$ of the donkeys. However, Atawalna et al. [43], observed the only blood parasite was Trypanosoma spp. (3.33\%). While Gizachew et al. [49], revealed that 54 donkeys (13.7\%) were positive for piroplasmid merozoites. T. equi and B. caballi were detected in $48(12.2 \%)$ and $7(1.8 \%)$ samples. Mekibib et al. [50] found only $1.3 \%$ and $0.5 \%$ of donkeys to be infected with $T$. equi and $B$. caballi, respectively, whereas Tefera et al. [51] found $2.1 \%$ and $1.0 \%$ of infected donkeys. Low prevalence data can be caused by false-negative results that may occur due to low parasitemia, especially in the late phase of infection. In this case, polymerase chain reaction carried out with ethylene diamine tetraacetate blood would give a higher prevalence. Another possibility is the in vitro cultivation of piroplasms in suspicious blood samples [52].

The different findings between our studies and other works might be due to the differences in the climate, agro-ecological conditions, variation in sample size, and sampling method differences. In addition, this might be associated with donkeys which could be neglected in these areas, kept under poor management conditions, and receiving less attention from owners. In our study revealed most donkeys harbor $G$. intestinalis and $G$. nasalis with high infestation with Ctenocephalides felis. The predominant consequence of $G$. intestinalis almost as the prevalence recorded by Hilali et al. [53] who recorded $98.3 \%$, this might be because of progress in climatic condition from 1987 to 2017. Our conclusion on Gasterophilus intestinalis infestation in Egypt is similar as Otranto et al. [54] who recorded two bimodal of life cycle during the year; in April and August, so the grown-up fly recorded in this time. A low predominance rate of $9.9 \%$ was recorded by Hoglund et al. [55], 43\% in Ireland [56], $53 \%$ in England [57]. While 95.2\% [54] and 94\% [58] were recorded in Italy; low prevalence recorded as $2.25 \%$ in Germany [59], $0.72 \%$ in Ethiopia [60]. While $100 \%$ [29] and 28.57\% [61] infestation with G. intestinalis and G. nasalis were recorded in Turkey So; Gasterophilosis was predominant around the Mediterranean area and all over the world Along these lines, $G$. intestinalis is the dominating bot fly in donkeys in Egypt. Other recent similar works in Egypt in specific bot fly in donkeys (Rhinoestrus spp.) were carried out by Hilali et al. [62], who recorded 100\% prevalence in Egypt all over the year.The prevalence rate was $86.6 \%$ in 39 inspected horses [63]. It was nearly similar to our study. Ticks in our study $(10 \%)$ transmit the theileriasis. Tick carries infections worldwide with significance diseases, influencing people, and animals [64].

In this way, in Egypt, this information has updated result of Hilali et al. [53]. Thus, this information is important in the therapeutic care of donkeys and also equines. The widespread of $G$. nasalis in the present examination was like the most records of investigations $[65,66]$.

\section{Conclusion}

The present study revealed that donkeys harbor different helminths, protozoal, and arthropods species with prevalence $(100 \%)$ with single or mixed infection. A detailed study of pathogenicity, treatment, and control strategies of each parasitic species is recommended with periodical treatment of such diseased animals.

\section{Authors' Contributions}

MMA, MMK, and MTA: Conception, design, and collection of the study. MMA, MMK, and MTA: Analysis and interpretation of the data. MMA, MMK, and MTA: Drafting and revising the manuscript critically for important intellectual content. All authors have read and approved the final manuscript.

\section{Acknowledgments}

The authors would like to thank all staff members of Giza zoo for facilitating this study work. No funding received for this work.

\section{Competing Interests}

The authors declare that they have no competing interests.

\section{References}

1. FAO. Mountain Farming is Family Farming, a contribution from mountain areas to the International Year of Family Farming 2014, http:/www.fao.org/docrep/019/i3480e/ i3480e. Last accessed on 15-07-2018.

2. Starkey, P. and Starkey, M. (2013) Regional and World Trends in Donkey Populations and Animal Traction Network for Eastern and Southern Africa Improving Donkey Utilization and Management. ATENSA, DebreZeit, Ethiopia. p230-237. 
3. Pereira, J.R. and Vianna, S.S. (2006) Gastrointestinal parasitic worms in equines in the Paraiba Valley, State of Sao Paulo, Brazil. J. Vet. Parasitol., 140: 289-295.

4. Getahun, T.K. and Kassa, T.Z. (2017) Prevalence and species of major gastrointestinal parasites of donkeys in Tenta Woreda, Amhara Regional State, Ethiopia. J. Vet. Med. Anim. Health, 9(2): 23-31.

5. Mahdy, O.A., Nassar, A.M., Mohamed, B.S. and Mahmoud, M.S. (2016) Comparative diagnosis utilizing molecular and serological techniques of Theileria equi infection in distinct equine populations in Egypt. Int. J. Chem. Tech Res., 9(6): 185-197.

6. Holland, W.G., Do, T.T. and Huong, N.T. (2003) The effect of Trypanosoma evansi infection on pig performance and vaccination against classical swine fever. Vet. Parasitol., 111(2-3): 115-123.

7. Soulsby, E.J.L. (1986) Helminths, Arthropods and Protozoa of Domesticated Animals. $7^{\text {th }}$ ed. Bailliere Tindall, London. p167-174.

8. Henriksen, S.A. and Pohlenz, J.F. (1981) Staining of Cryptosporidium by a modified Ziehl-Neelsen technique. Act. Vet. Scand., 22: 594-596.

9. Bancroft, J.D. and Stevens, A. (1996) The haematoxylin and eosin. In: Theory and Practice of Histological Techniques. $4^{\text {th }}$ ed. Churchill Living Stone, London, New York \& Tokyo.

10. Kornas, S., Gawor, J., Cabaret, J., Molenda, K., Skalska, M. and Nowosad, B. (2009) Morphometric identification of equid cyathostome (Nematoda: Cyathostominae) infective larvae. Vet. Parasitol., 162: 290-294.

11. Lichtenfels, J.R. (1975) Helminths of domestic equids. Illustrated keys to genera and species with emphasis on North American Forms. Proc. Helminthol. Soc. Washin., 42: 1-92.

12. Tolliver, S.C. (2000) A Practical Method of Identification of the North American Cyathostomes (Small Strongyles) in Equids in Kentucky. Agricultural Experiment Station, University of Kentucky, College of Agriculture, Department of Veterinary Science, Lexington, KY, USA. Bulletin Number SR-2000-1.

13. Bush, A.O., Lafferty, K.D., Lotz, J.M. and Shostak, A.W. (1997) Parasitology meets ecology on its own terms: Margolis et al. revisited. J Parasitol., 83: 575-583.

14. Vereruysse, J., Harris, E.A., Kaboret, Y.Y., Pangui, L.J. and Gibson, D.I. (1986) Gastro-intestinal helminths of donkeys in Burkina Faso. Z. Parasitenkd., 72: 821-825.

15. Pandey, V.S., Ouhelli, H. and Verhulst, A. (1992) Epidemiological observations on stomach worms of donkeys in Morocco. Vet. Res. Commun., 16: 273-279.

16. Aypak, S. and Burgu, A. (2013) Prevalence of the stomach helminths in equines. Vet. Fak. Derg., 24(1): 29-35.

17. Shrikhande, G., Rewatkar, S., Deshmukh, S., Maske, D. and Raghorte, Y. (2009) The incidence of helminth parasites in donkeys. Vet. World, 2(6): 224.

18. Ayele, G., Feseha, G., Bojia, E. and Joe, A. (2006) Prevalence of gastrointestinal parasites of donkeys in Dugda Bora District, Ethiopia. Livest. Res. Rural Dev., 18: 2-6.

19. Fikru, R., Reta, D., Teshale, S. and Bizunesh, M. (2005) Prevalence of equine gastrointestinal parasites in western highlands of Oromia, Ethiopia. Bull. Anim. Health Prod. Afr., 53(3): 161-1.

20. Alemayehu, H. (1995) Prevalence of Equine Helminthiasis in Specific Site of Arsi and Bale Region. DVM Thesis, Addis Ababa University, FVM, Debrezeit.

21. Sinasi, U. (2009) A survey on helminth infections of equines in the Central Black Sea region, Turkey. J. Vet. Anim. Sci., 33(5): 373-378.

22. Ayele, G. and Dinka, A. (2010) Study on strongyles and parascaris parasites population in working donkeys of central Shoa, Ethiopia. Livest. Res. Rural Dev., 22(12): 1-5.

23. Yoseph, S., Feseha, G. and Abebe, W. (2001) Survey on helminthosis of equines in Wonchi, Ethiopia. J. Ethiop. Vet. Assoc., 5: 47-46.
24. Takele, B. and Nibret, E. (2013) Prevalence of gastrointestinal helminthes of donkeys and mules in and around Bahir Dar, Ethiopia. Ethiopian Vet. J., 17(1): 13-30.

25. Tolliver, S.C., Lyons, E.T. and Drudge, J.H. (1985) Species of small strongyles and other internal parasites recovered from donkeys at necropsy in Kentucky. Proc. Helminthol. Soc. Wash., 52(2): 260-265.

26. Eysker, M. and Pandey, V.S. (1989) Small strongyles infections in donkeys from the highveld in Zimbabwe. Vet. Parasitol., 30(4): 345-349.

27. Matthee, S., Krecek, R.C. and Milne, S.A. (2000) Prevalence and biodiversity of helminth parasites in donkeys from South Africa. J. Parasitol., 86(4): 756-762.

28. Kuzmina, T.A., Kharchenko, V.A., Trawford, A. and Getachew, M. (2007) The Strongylid Nematodes of Working Donkeys from Ethiopia. $21^{\text {th }}$ International Conference World Assassin for the Advancement of Veterinary Parasitology (WAAVP), Gent, Belgium. p380.

29. Getachew, M., Trawford, A., Feseha, G. and Reid, S.W. (2010) Gastrointestinal parasites of working donkeys of Ethiopia. Trop. Anim. Health Prod., 42(1): 27-33.

30. Trawford, A. and Getachew, M. (2008) Parasites. In: Duncan, J. and Hadrill, D., editors. The Professional Handbook of the Donkey. $4^{\text {th }}$ ed. Whittet Books Limited., South House, Yatesbury, Wiltshire, UK. p82-101.

31. Wells, D., Krecek, R.C., Wells, M., Guthrie, A.J. and Lourens, J.C. (1998) Helminth levels of working donkeys kept under different management systems in the Moretele 1 district of the North West Province, South Africa, Vet. Parasitol., 77: 163-177.

32. Sapkota, C.R. (2009) A Report on Prevalence of Helminthes Parasites in Mules of Brick Kiln of Lalitpur District. Himalayan College of Agricultural Sciences and Technology. Purbanchal University Gatthaghar, Bhaktapur.

33. Pal, R.A. and Qayyum, M. (1992) Breed, age and sex wise distribution of helminthes of sheep and goats in and around Rawalpindi region. Pak. Vet. J., 12: 60-63.

34. Souza, D.P.N., Bomfim, T.C., Huber, F., Abboud, L.C. and Gomes, R.S. (2009) Natural infection by Cryptosporidium sp., Giardia sp. and Eimeria leuckarti in three groups of equines with different handlings in Rio de Janeiro. Braz. Vet. Parasitol., 160: 327-333.

35. Laatamnaa, A., Wagnerová, P., Sak, B., Kveto`nová, D., Xiao, L., Roste, M., McEvoy, J., Saadig, A.R., Aissi, M. and Kvác, M. (2015) Microsporidia and Cryptosporidium in horses and donkeys in Algeria: Detection of a novel Cryptosporidium hominis subtype family (Ik) in a horse. Vet. Parasitol., 208: 135-142.

36. Majewska, A.C., Solarczyk, P., Tamang, L. and Graczyk, T.K. (2004) Equine Cryptosporidium parvum infections in western Poland. Parasitol. Res., 93: 274-278.

37. Sturdee, A.P., Bodley-Tickell, A.T., Archer, A. and Chalmers, R.M. (2003) Long-term study of Cryptosporidium prevalence on a lowland farm in the United Kingdom. Vet. Parasitol., 116: 97-113.

38. Caffara, M., Piva, S., Pallaver, F., Iacono, E. and Galuppi, R. (2013) Molecular characterization of Cryptosporidium spp. from foals in Italy. Vet. J., 198: 531-533.

39. Grinberg, A., Pomroy, W.E., Carslake, H.B., Shi, Y., Gibson, I.R. and Drayton, B.M. (2009) A study of neonatal cryptosporidiosis of foals in New Zealand. N. Z. Vet. J., 5: 284-289

40. Wannas, H.Y., Dawood, K. and Gassem, G. (2012) Prevalence of gastrointestinal parasites in horses and donkeys in Al Diwaniyah governorate, Al-Qadisiya. J. Vet. Med. Sci., 11: 841-855.

41. Studzinska, B.M., Tomczuk. K. and Sadzikowski, A. (2008) Prevalence of Eimeria leuckarti in horses and usefulness of some coproscopical methods for its detection. Bull. Vet. Inst. Pulawy, 52: 541-544.

42. Ghahfarrokhi, E.K., Ahmadi, A., Shahraki, S.G. andAzizi, H. (2014) Eimeria leuckarti (Flesch, 1883; Reichenow, 1940) 
from worker horses and donkeys of Shahrekord, Iran. Int. J. Adv. Biol. Biomed. Res., 2(6):1980-1984.

43. Atawalna, J., Emikpe, B.O., Sallah, E.K., Shaibu, W. and Folitse, R.D. (2015) The health problems, gastrointestinal and blood parasites commonly associated with donkeys in the upper east region of Ghana. Afr. J. Biomed. Res., 8: $37-41$.

44. Nakayima, J., Kabasa, W., Aleper, D. and Okidi, D. (2017) Prevalence of endo-parasites in donkeys and camels in Karamoja sub-region, North-eastern Uganda. J. Vet. Med. Anim. Health, 9(1): 11-15.

45. Fukuyo, M., Battsetseg, G. and Byambaa, B. (2002) Prevalence of Sarcocystis infection in horses in Mongolia, Southeast Asian. J. Trop. Med. Public Health, 33: 718-719.

46. Khan, A., Khan, M.S., Avais, M., Ijaz, M., Ali, M.M. and Abbas, T. (2013) Prevalence, hematology, and treatment of balantidiasis among donkeys in and around Lahore, Pakistan. Vet. Parasitol., 196: 203-205.

47. Dissanayake, S., Rajapakse, J. and Rajakaruna, R.S. (2017) Gastrointestinal parasites of domesticated and Feral Horses (Equus caballus) in Sri Lanka. Ceylon J. Sci., 46: 17-26.

48. Mushi, E.Z., Binta, M.G., Chabo, R.G. and Monnafela, L. (2003) Seasonal fluctuation of parasitic infestation in donkeys (Equus asinus) in Oodi village, Kgatleng District, Botswana. J. S. Afr. Vet. Assoc., 74(1): 24-26.

49. Gizachew, A., Schuster, R.K., Joseph, S., Wernery, R., Georgy, N.A., Elizabeth, S.K., Asfaw, Y. and Regassa, F. (2013) Piroplasmosis in donkeys. A hematological and serological study in central Ethiopia. J Equine Vet. Sci., 33: 18-21.

50. Mekibib, B., Manegerew, M., Tadesse, A., Abuna, F., Megersa, B. and Regassa, A. (2010) Prevalence of haemoparasites and associated risk factors in working donkeys in Adigurem and Kwiha districts of Tigray region, Northern Ethiopia. J. Anim.Vet. Adv. 9(17):2249-2255.

51. Tefera, M., Worku, A., Tolosa, T. and Bitew, M. (2011) Prevalence and risk factors for donkey babesiosis in and around Debre Zeit, Central Ethiopia. Vet. Res., 4: 56-60.

52. Zweygart, E., Just, M.C., Waal, D.T. and LopezRebollar, L.M. (1999) In vitro diagnosis of Babesia equi. In: Wernery U, Wade FJ, Mumford JA, Kaaden OR, editors. Equine Infectious Diseases VIII. In: Proceedings of the $8^{\text {th }}$ Equine Infectious Diseases Conference. Newmarket: R \& W Publications, Dubai, UAE. p232e6.

53. Hilali, M., Derhalli, F.S. and Baraka, A. (1987) Incidence and monthly prevalence (Equus asinus) in Egypt. Vet. Parasitol., 23: 297-305.

54. Otranto, D., Milillo, P., Capelli, G. and Colwell, D.D.
(2005) Species composition of Gasterophilus spp. (Diptera, Oestridae) causing equine gastric myiasis in southern Italy: Parasite biodiversity and risks for extinction. Vet. Parasitol., 133: 111-118.

55. Hoglund, J., Ljungstrom, B.L., Nilsson, O., Lundquist, H., Osterman, E. and Uggla, A. (1997) Occurrence of Gasterophilus intestinalis and some parasitic nematodes of horses in Sweden. Acta Vet. Scand., 38: 157-165.

56. Sweeney, H.J. (1990) The prevalence and pathogenicity of G. intestinalis larvae in horses in Ireland. Irish Vet. J., 43: 67-73.

57. Edwards, G.T. (1982) The prevalence of Gasterophilus intestinalis in horses in northern England and Wales. Vet. Parasitol., 11: 215-222.

58. Principato, M. (1988) Classification of the main macroscopic lesions produced by larvae of Gasterophilusspp. (Diptera: Gasterophilidae) in free-ranging horses in Umbria. Cornell Vet., 78: 43-52.

59. Rehbein, S., Visser, M. and Winter, R. (2013) Prevalence, intensity and seasonality of gastrointestinal parasites in abattoir horses in Germany. Parasitol. Res., 112: 407-413.

60. Mezgebu, T., Tafess, K. and Tamiru, F. (2013) Prevalence of gastrointestinal parasites of horses and donkeys in and around Gondar Town, Ethiopia. Open J. Vet. Med. (OJVM), 3(6): 267-272.

61. Nalan, Ö., Kamile, B., Özlem, O. and Serdar, D. (2010) Presence of Gasterophilus species in horses in van region. Vet. Fak. Derg., 21(2): 87-90.

62. Hilali, M., Mahdy, O.A. and Attia, M.M. (2015) Monthly variations of Rhinoestrus spp. (Diptera: Oestridae) larvae infesting donkeys in Egypt: Morphological and molecular identification of third stage larvae. J. Adv. Res., 6: 1015-1021.

63. AL Anazi, A.D. and Alyousif, M.S. (2011) Prevalence of non-gastrointestinal parasites strongyle of horses in Riyadh region of Saudi Arabia. Saudi J. Biol. Sci., 18: 299-303.

64. Nicholson, W.L., Paddock, C. D., Demma, L., Traeger, M., Johnson, B., Dickson, J., McQuiston, J. and Swerdlow, J. (2006) Rocky mountain spotted fever in Arizona: Documentation of heavy environmental infestations of Rhipicephalus sanguineus at an endemic site. Ann. N. Y. Acad Sci., 1078: 338-341.

65. Reinemeyer, C.R., Smith, S.A., Gabel, A.A. and Herd, R.P. (1984) Prevalence and intensity of internal parasites of horses in the USA. Vet. Parasitol., 15(1): 75-83.

66. Bucknell, D.G., Gasser, R.B. and Beveridge, I. (1995) The prevalence and epidemiology of gastrointestinal parasites of horses in Victoria, Australia. Int. J. Parasitol., 25(6): 711-724. 